\title{
Screening of Endophytic Bacteria Isolated From Mimosa pudica in Bali Island
}

\author{
Dewa Gede Wiryangga Selangga ${ }^{1 *}$ and Listihani ${ }^{2}$ \\ ${ }^{1}$ Agrotechnology Department, Faculty of Agriculture, Warmadewa University, Indonesia \\ ${ }^{2}$ Agrotechnology Department, Faculty of Agriculture and Business, Mahasaraswati University, Indonesia \\ *dewanggaselangga@gmail.com
}

\begin{abstract}
This study aims to determine the screening of endophytic bacteria isolated from Mimosa pudica in Bali Island. This research was conducted from September 2020 to January 2021 at the Plant Disease Laboratory, Faculty of Agriculture, Udayana University, Denpasar. Isolation of endophytic bacteria was carried out by taking a sample of the root of the shy daughter plant which was then washed and dried on a tissue. Hypersensitivity test followed Klement and Goodman (1967) by growing bacteria in a petri dish containing 100\% TSA and NA.Tests were carried out by growing endophytic bacteria in 100\% NA and TSA media. Isolation of the roots of the Mimosa pudica plant resulted in 43 isolates. The resulting isolates then passed the hypersensitive test so that 27 isolates were selected. A total of 27 isolates were then tested for hemolysis on blood agar. The final results obtained were 12 endophytic bacterial isolates which were then used in the next practicum. The results showed that the endophytic bacterial isolates were not able to inhibit the fusarium sp. and Phytophthora sp. when using the inhibition percentage formula. This is because the average diameter of the pathogenic fungi colonies in the control treatment $(R 1)$ with the average diameter of the pathogenic fungi colonies in the endophytic treatment (R2) has the same size so that when calculated by the percentage inhibition formula it results in the number 0 which means no. there is a zone of inhibition.
\end{abstract}

Keywords: endophytic bacteria; fusarium sp.; Mimosa pudica.; and Phytophthora sp.

\section{Introduction}

Plant pathogenic bacteria can cause various symptoms of plant diseases and can attack many types of plants. About 100 species of bacteria are known to be pathogens in plants [1]. Most plant pathogenic bacteria are facultative saprophytes and can be cultured on artificial nutrient media. Bacteria in general can be rod-shaped, spherical, spiral, or filamentous, measuring 0.6 to $3.5 \mu \mathrm{m}$ and some bacteria can move with the help of their flagella. Bacterial reproduction is generally through rapid cell division following a quadratic pattern, which can increase the number of bacterial populations in a very short time. As a defense structure, some bacteria form spores, namely in the Bacillus group and forming conidia in filamentous bacteria. Plant diseases caused by bacteria thrive in humid tropics where environmental conditions, especially humidity determine the development of pathogens [2].

Plant pathogenic bacteria can cause as many types of symptoms as those caused by fungi. Symptoms caused by plant pathogenic bacteria can include leaf spots and blight, soft rot of fruit, roots, and storage material, and can also cause wilting, abnormal growth, scabies, and cancer [3]. One type of the same symptom can be caused by several different genera of plant pathogenic bacteria, but each bacterial genus can cause a different type of disease symptom. For example, the Agrobacterium species can only cause symptoms of an overgrowth of the plant organs it infects. However, symptoms of overgrowth can also be caused by bacteria from the genus Rhodococcus and Pseudomonas.

Studying bacteria cannot be separated by carrying out isolation and identification. The method 
of isolation and identification of bacteria originating from plant tissue or the soil is by using selective artificial growing media. Selective media contain nutrients that stimulate the growth of certain bacteria and at the same time inhibit the growth of other types of bacteria. Identifying bacteria positively usually requires more than one culture on selective media, because to get only one type of bacteria that grows on selective media is rarely found. Previously, the rapid identification and differentiation of bacterial genera were carried out by extracting and comparing the structure of fatty acids contained in bacterial cell membranes which were called fatty acid profile analyses. The same can be done for membrane proteins, enzymes, and isoenzymes in bacterial cell membranes.

Control of plant diseases caused by bacteria is relatively difficult to control. One of the most widely used control methods is to use antagonistic agents because they are effective in suppressing pathogens without harming the planting environment. Studies on the control of plant pathogenic bacteria using antagonistic microbes are still being carried out to increase the study of agricultural science in particular.

\section{Material and Methods}

This research was conducted from September 2020 to January 2021 at the Plant Disease Laboratory, Faculty of Agriculture, Udayana University, Denpasar. Sampling was done by taking the root of the Mimosa pudica plant. The sampling location is in the Taro Adat Forest, Tegallalang, Gianyar. The samples that have been taken are stored in plastic bags to avoid damage to plant tissue. Isolation of endophytic bacteria was carried out by taking a sample of the root of the shy daughter plant which was then washed and dried on a tissue. As much as 1 gram of plant roots surface sterilized by immersing in $70 \%$ alcohol for 3 minutes, $2 \% \mathrm{NaOCl}$ added with $0.05 \%$ Tween 20 for 3 minutes and rinsed with sterile distilled water 3 times. The sample was dried with sterile tissue then attached to $20 \%$ tryptic soy agar (TSA) medium and $20 \%$ nutrient agar (NA) which were used as controls and incubated for 24 hours. The sample is then macerated or crushed using a sterile mortar until smooth with the addition of 1:10 water. Furthermore, serial dilutions are carried out up to 10-4. Suspensions at dilution levels of 10-2, 10-3, and 10-4 were grown on 20\% TSA and 20\% NA media and then incubated at room temperature for 48 hours.

Hypersensitivity test followed Klement and Goodman (1967) by growing bacteria in a petri dish containing $100 \%$ TSA and NA. This test is carried out by following the method of Beutin (1991). Endophytic bacteria that do not show the formation of a hemolytic zone/change of 12 media color ( $\lambda$-hemolysis) will be used for further testing [4]. Tests were carried out by growing Fusarium sp. and Phytophthora sp. along with endophytic bacteria on PDA media. Endophytic bacteria were grown in $1 / 4$ of the center of the petri dish, then each fungi Fusarium sp. and Phytophthora sp. grown in the center of a petri dish. After 5 days, measurements of the growth of the diameter of Fusarium sp. which points towards bacteria and in the opposite direction to bacteria.

Tests were carried out by growing endophytic bacteria in 100\% NA and TSA media. Cultures aged 24-48 hours are then harvested using sterile distilled water. Soak the seeds for 2 hours in a suspension of endophytic bacteria. The seeds have been soaked for 2 hours, then seeded in sterile soil media. Observations were made 2 weeks after sowing. The variables observed were plant height.

\section{Results and Discussion}

\subsection{Results and Discussion}

Isolation of the roots of the Mimosa pudica plant resulted in 43 isolates. The resulting isolates then passed the hypersensitive test so that 27 isolates were selected. A total of 27 isolates were then tested for hemolysis on blood agar. The final results obtained were 12 endophytic bacterial isolates 
which were then used in the next practicum.
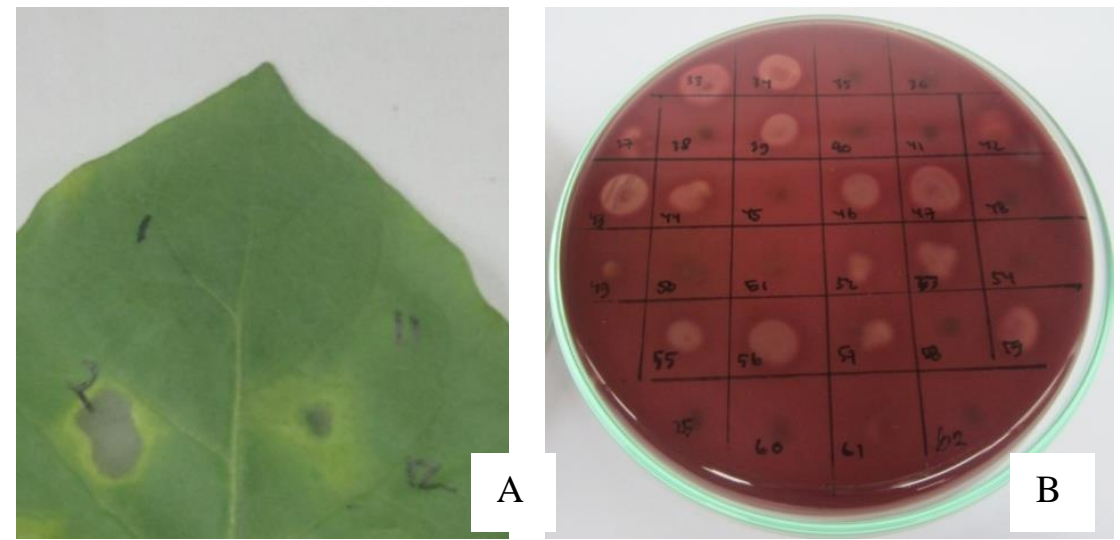

Figure 1

Hypersensitivity test results on tobacco leaves (A); hemolysis test results on bacterial isolate (B).

Hypersensitive test shows, there is a hypersensitive response if the isolate contains pathogenic bacteria. This is due to the protective power of plant cells that kill some of the cell tissue to avoid the expansion of pathogenic infections, but if the suspense injected isolates do not show a hypersensitive response, it means the isolate contains endophytic bacteria. According to [2], endophytic microbes are microbes that live in plant tissue at a certain period and can live by forming colonies in plant tissues without harming the host.

The presence of endophytic bacteria in plant tissue can provide certain advantages to host plants and play a role in biotechnology because their potential use as a genetic vector of flowers, a source of secondary metabolites, and biological control agents has shown an increase in host survival. against fungal pathogens in some plants associated with endophytic bacteria [3].

The hemolysis test aims to classify certain microorganisms by observing the ability of bacterial colonies to induce hemolysis when planted in blood agar (blood agar). The results of the practicum showed that 15 isolates succeeded in destroying the red blood cells in the agar blood, thus showing hemolism. Some of these isolates are thought to be pathogenic bacteria in mammals and are not classified as endophytic bacteria.

Endophytic bacteria can enter the plant tissue generally through the roots, but some parts of the plant, such as flowers, stems, leaves (through the stomata), and cotyledons, can also be the entry route for endophytic bacteria. Endophytic bacteria that have entered the plant tissue will be colonized in certain parts or can also spread to all parts of the plant. The results of the practicum showed that the number of endophytic bacterial isolates was lower than the isolates from the stem. Bacon and Hinton (2006) stated that the number of endophytic bacteria in plants cannot be determined with certainty, but these bacteria can be detected by isolating them using artificial propagation media, such as nutrient agar (NA) or tryptic soy agar (TSA) [4].

The interaction of endophytic bacteria and plants is a form of symbiosis. The symbiosis between plants and endophytic bacteria is neutral, mutualism, or commensalism [5]. The symbiosis of mutualism between endophytic bacteria and plants, in this case, endophytic bacteria get nutrients from the results of plant metabolism and protect plants against pathogens, while plants get the nutrient derivatives and active compounds needed during their life [6].

The results showed that the plants given the endophytic bacterial isolate suspension had a higher growth rate than the control. The highest growth was shown by K2N3 isolates with a height of $9 \mathrm{~cm}$, followed by P3N1 isolates with a height of $8.7 \mathrm{~cm}, \mathrm{P} 2 \mathrm{~N} 1$ and P3T4 isolates with a height of $7.3 \mathrm{~cm}$, and 11 other isolates with plant heights ranging from 5.2 to $7.0 \mathrm{~cm}$, while control plants had a high 
average $4 \mathrm{~cm}$. The difference in growth is because endophytic bacteria are reported to be able to increase plant growth, break down pathogenic cell walls, and inhibit pathogen growth by producing anti-microbial compounds such as siderophore [7]. Siderophores are organic compounds other than antibiotics that can play a role in the biological control of plant diseases [8].

Table 1

Average Height of Tomato Plants Treated with Endophytic Bacteria Isolates.

\begin{tabular}{|c|c|c|c|c|c|c|c|c|}
\hline \multirow{2}{*}{ No } & \multirow{2}{*}{ Treatment } & \multicolumn{6}{|c|}{ Replication } & \multirow{2}{*}{ Averag } \\
\hline & & 1 & 2 & 3 & 4 & 5 & 6 & \\
\hline 1 & $\mathrm{P} 2 \mathrm{~N} 1$ & 8 & 7 & 7 & 7 & 8 & 7 & 7.3 \\
\hline 2 & P3N3 & 5 & 5 & 6 & 6 & 5 & 6 & 5.5 \\
\hline 3 & Р3T9 & 8 & 6 & 6 & 7 & 5 & 4 & 6.0 \\
\hline 4 & P3T4 & 8 & 7 & 8 & 7 & 7 & 7 & 7.3 \\
\hline 5 & P3T2 & 7 & 6 & 6 & 6 & 6 & 7 & 6.3 \\
\hline 6 & P3T3 & 5 & 7 & 7 & 7 & 5 & 7 & 6.3 \\
\hline 7 & P3T11 & 6 & 6 & 6 & 6 & 6 & 6 & 6.0 \\
\hline 8 & $\mathrm{~K} 2 \mathrm{~T} 4$ & 7 & 6 & 5 & 5 & 6 & 6 & 5.8 \\
\hline 9 & P2N8 & 6 & 5 & 5 & 5 & 5 & 9 & 5.8 \\
\hline 10 & P2N9 & 7 & 7 & 7 & 7 & 7 & 7 & 7.0 \\
\hline 11 & P2N6 & 5 & 5 & 5 & 5 & 5 & 6 & 5.2 \\
\hline 12 & P3N1 & 10 & 10 & 10 & 7 & 8 & 7 & 8.7 \\
\hline 13 & $\mathrm{~K} 2 \mathrm{~N} 1$ & 7 & 7 & 7 & 7 & 7 & 7 & 7.0 \\
\hline 14 & K2N3 & 9 & 9 & 9 & 9 & 9 & 9 & 9.0 \\
\hline 15 & K3T1 & 5 & 5 & 5 & 5 & 5 & 5 & 5.0 \\
\hline 16 & Control & 4 & 3 & 4 & 4 & 5 & 4 & 4.0 \\
\hline
\end{tabular}

Hallman (2001) stated that endophytic bacteria can protect plants from soil-borne pathogens [9]. Endophytic bacteria can colonize the root cortex tissue and produce metabolites that suppress pathogens to induce plant resistance. Antibiotic compounds produced by antagonistic bacteria can act directly as a bactericide against pathogenic bacteria and an elicitor for plant resistance to disease [10].

Endophytes support growth enhancement through a number of the same mechanisms. These include phosphate dissolving [11] ; [12], IAA hormone [13] and production of siderophore a [14]. Endophytes also help in the availability of essential elements for plants (Pirttila et al. 2004). In addition, other beneficial effects are associated with endophytic, namely assisting in osmotic regulation, stomata, morphological modification (as in roots), increased mineral uptake, and changes in nitrogen accumulation and metabolism [15].

Some soil microbes can produce plant hormones that can stimulate plant growth, the hormones produced will be absorbed by plants so that plants will grow faster or bigger. Liu et al. (1995) stated that the increase in plant height was caused by the rhizobacteria group of bacteria that could produce auxin and gibberellin hormones [16]. This hormone will stimulate plant growth so that it affects the height, wet weight, and dry weight of the plant. Some antagonistic organisms function as biological controllers, growth promoters, and inducers of resistance to pathogens [17].

The increase in plant growth by treatment of endophytic bacteria is thought to be because endophytic bacteria can increase nitrogen fixation, photosynthetic activity, and production of indole acetic acid (IAA) [18] ; [19]. [20] report that endophytic bacteria can increase plant growth because they produce important components for plant growth, such as mineral phosphate, acid phosphatase activity, presence of 1-aminocyclopropane-1-carboxylic acid deaminase (ACC). In addition, the interaction of endophytic bacteria with plants can produce elicitors in the induction of resistance to produce lipopolysaccharides which act as elicitors in resistance induction that specifically bind to receptors on the surface of plant cells [21]. 


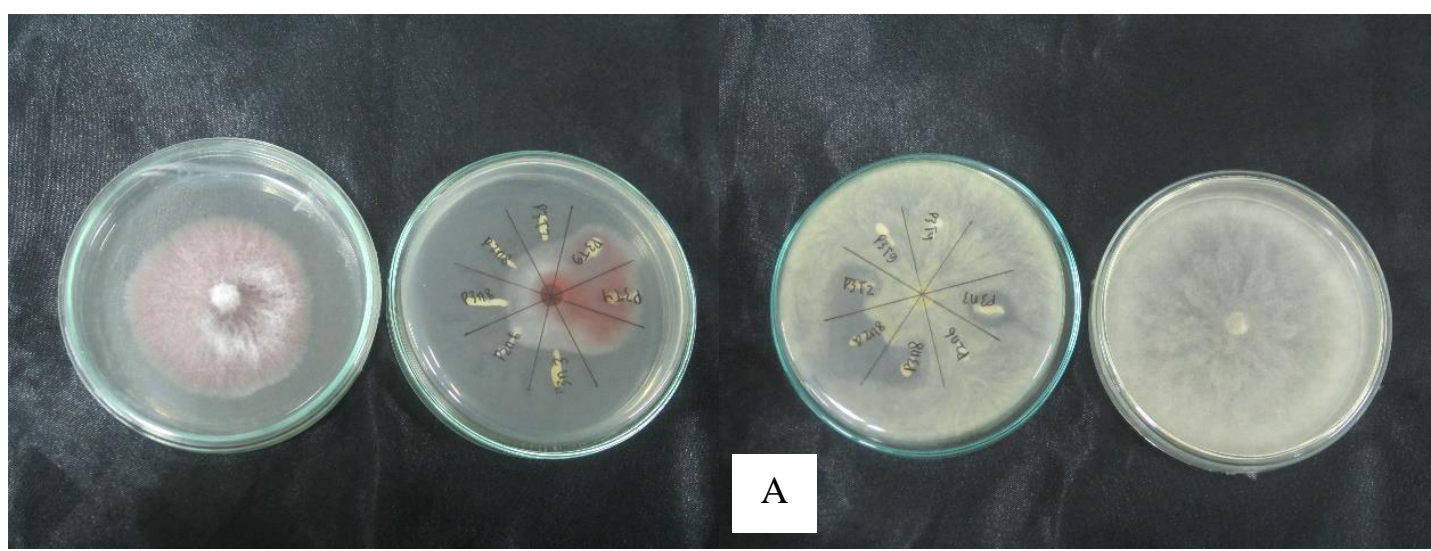

Figure 2

Test of the antagonistic ability of endophytic bacteria against Fusarium sp. (A) and Phytophthora sp. (B)

The results of the antagonistic ability test between endophytic bacteria against Fusarium sp. and Phytophthora sp. showed that 4 isolates of endophytic bacteria were able to produce clear zones (Figure 2). The formation of the clear zone is thought to be the activity formed by endophytic bacteria. According to [22] the formation of an inhibition zone indicates that these endophytic bacteria may contain antibiotics. Antibiotics are classified as secondary metabolites produced by endophytic bacteria in their metabolic pathways and by enzymes that are not required for the growth and maintenance of plant cells. Antibiotics are substances produced by living organisms that in low concentrations can inhibit or kill other organisms.

Schulz et al., (2006) stated that in addition to the formation of an inhibition zone, competition is considered a very important factor in the control of pathogenic fungi by endophytic bacteria, inhibition zone competition occurs when both organisms are in the same place and use the same nutrients. The P2N8, P3N8, P3N3, and P3T3 isolates obtained from the antagonist test results were then re-tested for their antagonistic power against Fusarium sp. and Phytophthora sp. The test results can be seen in Table 2 [23].

Table 2

Data on Inhibition Test of Endophytic Bacteria Isolates against Fusarium sp. and Phytophthora sp.

\begin{tabular}{cccc}
\hline Treatment & R1 & R2 & P \\
\hline P2N8 & 3 & 3 & 0 \\
P3N8 & 3 & 3 & 0 \\
P3N3 & 3 & 3 & 0 \\
P3T2 & 3 & 3 & 0 \\
Control & 3 & 3 & 0 \\
\hline
\end{tabular}

Information:

$\mathrm{P}=$ percentage inhibition

$\mathrm{R} 1=$ average diameter of pathogenic fungi colonies in the control treatment

$\mathrm{R} 2=$ average diameter of pathogenic fungi colonies in endophytic treatment

The results of the practicum showed that the endophytic bacterial isolates were not able to inhibit the fungus Fusarium sp. and Phytophthora sp. when using the inhibition percentage formula. This is because the average diameter of the pathogenic fungi colonies in the control treatment (R1) with the average diameter of the pathogenic fungi colonies in the endophytic treatment (R2) has the same size so that when calculated by the percentage inhibition formula it results in the number 0 which means no. there is a zone of inhibition. However, when seen in the petri dish, there is an inhibition zone in each isolate (Figure 3 and 4). 


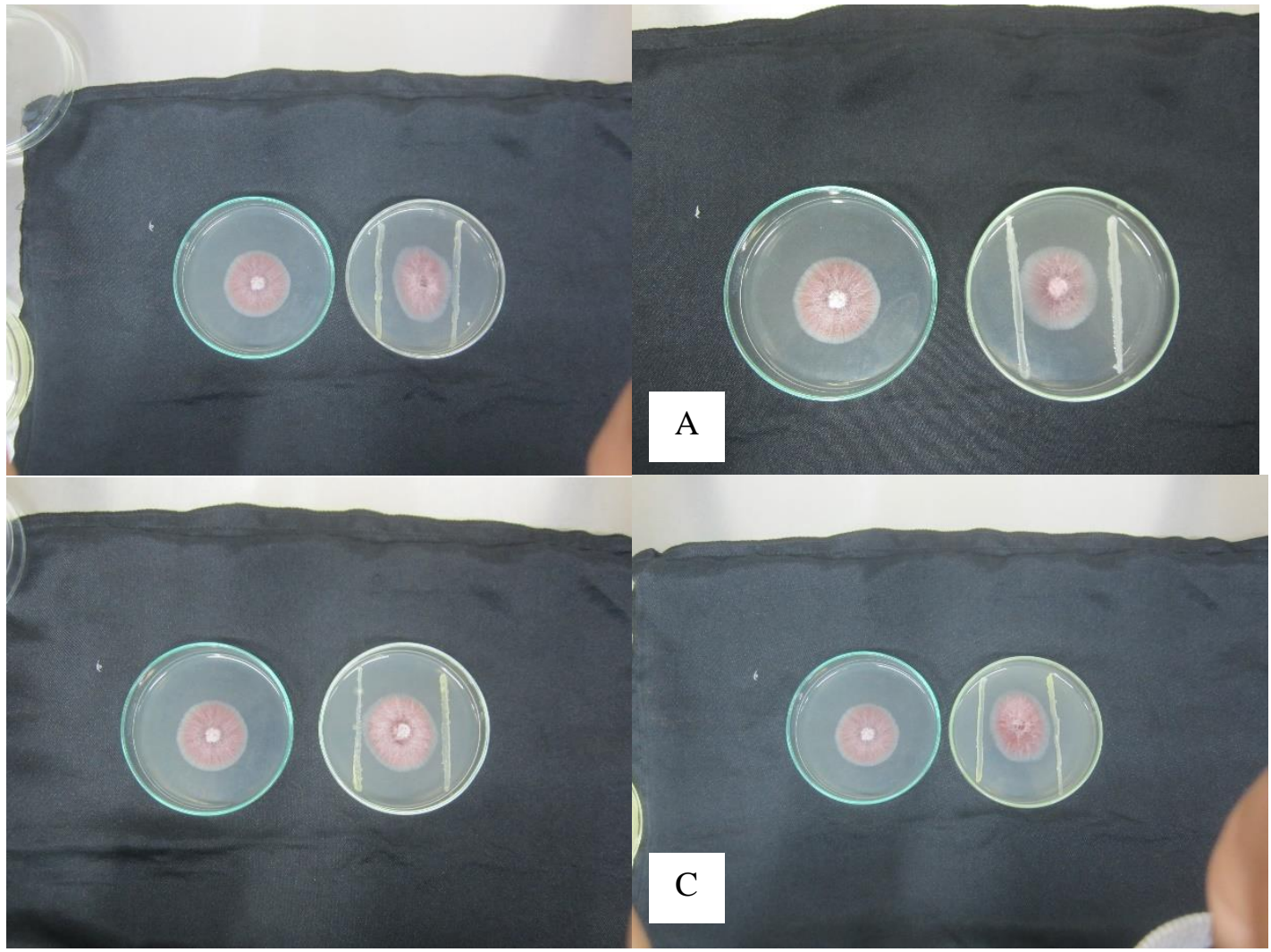

Figure 3

Test of the inhibitory ability of endophytic bacteria against the pathogenic fungi Fusarium sp., Isolate P2N8 (A), Isolate P3N3 (B), Isolate P3N8 (C), and Isolate P3T2 (D).

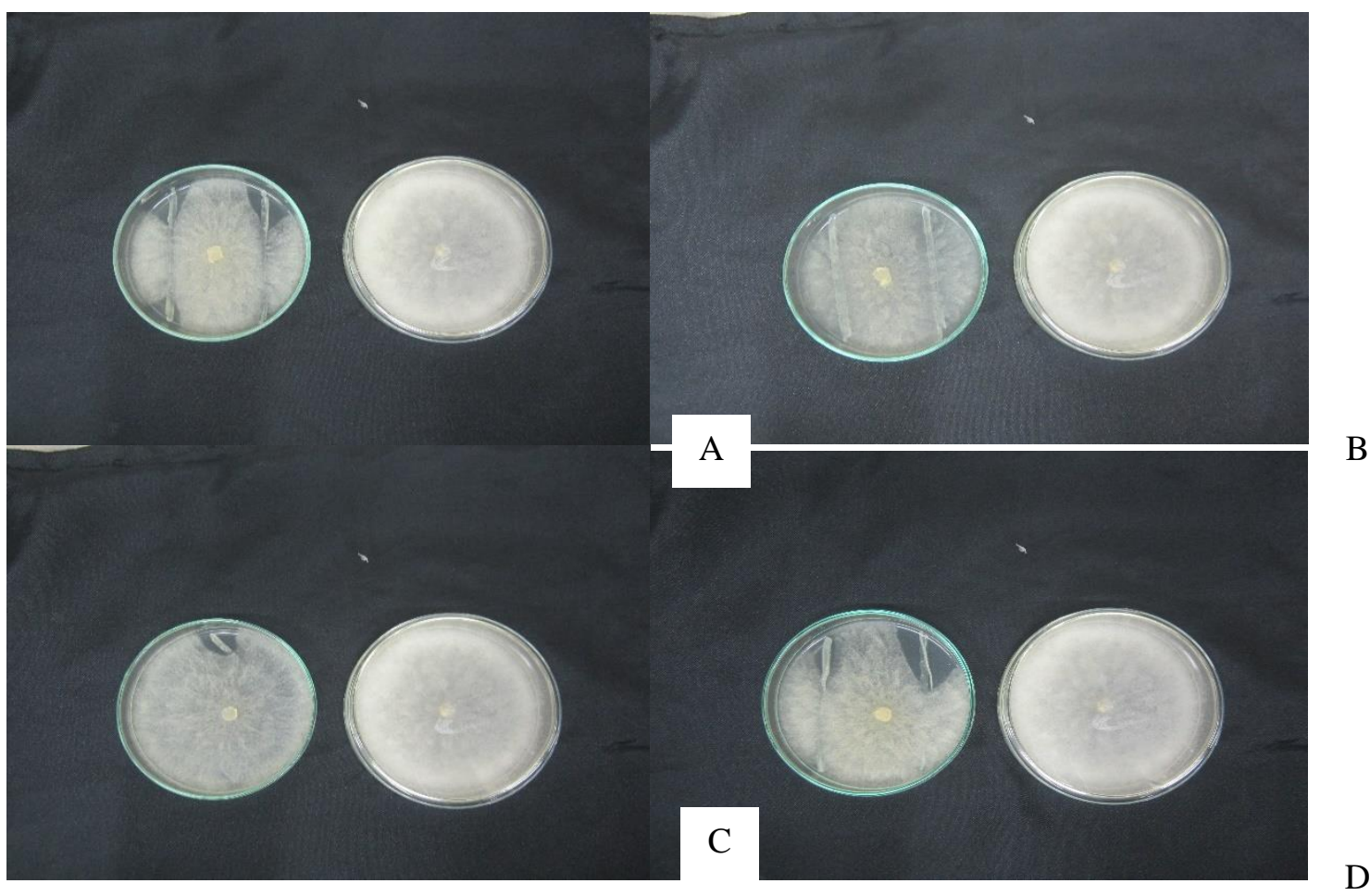

Figure 4

Test of the inhibitory ability of endophytic bacteria against the pathogenic fungi Phytophthora sp., Isolate P2N8 (A), Isolate P3N3 (B), Isolate P3N8 (C), and Isolate P3T2 (D) 
The ability of endophytic bacteria Isolate P2N8, Isolate P3N3, Isolate P3N8 and Isolate P3T2 in inhibiting the development of the fungus Fusarium sp. seen in the formation of clear zones in each experiment. But the zone formed is not too significant and looks striking. The movement of the fungus Fusarium sp. Not to the side, but the movement tends to the upward, so it is suspected that the isolates can suppress the development of fungi. The same conditions can be seen in (Figure 4).

The ability of endophytic bacteria Isolate P2N8, Isolate P3N3, Isolate P3N8 and Isolate P3T2 in inhibiting the development of the fungi Phytophthora sp. seen in the formation of clear zones in each experiment. But the zone formed is not too significant and looks striking. Movement of the fungus Phytophthora sp. is not able to create a clear zone maximally, it is suspected that because the concentration of fungi is too large compared to the concentration of endophytic bacteria, endophytic bacteria will be able to inhibit the fungus maximally if the concentration is large enough.

The low potential of endophytic bacteria in suppressing the growth of pathogenic fungi is due to several factors. Most of the unknown regulation of the anti-fungal metabolites exhibited by endophytic bacteria. However, antibiosis is one of the mechanisms used by endophytic bacteria in controlling pathogenic fungi.

According to Rahma (2000), the stationary growth phase is a phase in endophytic bacteria that produces secondary metabolites [24]. The metabolite activity of these endophytic bacteria greatly determines the formation of the inhibition zone or clear zone because these endophytic bacteria are ready to secrete their metabolites so that they can be used as antibacterial or anti-fungal. According to Stobel (2012), the formation of the inhibition zone can also be influenced by environmental factors and excessive test bacteria so that the effect of metabolites produced by endophytic bacteria is not significant on the growth of Fusarium sp. Bacteria. and Phytophthora sp [25].

\section{Conclusion}

Isolation of the roots of the Mimosa pudica plant resulted in 43 isolates. The resulting isolates then passed the hypersensitive test so that 27 isolates were selected. A total of 27 isolates were then tested for hemolysis on blood agar. The final results obtained were 12 endophytic bacterial isolates which were then used in the next practicum. The results showed that the endophytic bacterial isolates were not able to inhibit the fusarium sp. and Phytophthora sp. when using the inhibition percentage formula. This is because the average diameter of the pathogenic fungi colonies in the control treatment (R1) with the average diameter of the pathogenic fungi colonies in the endophytic treatment (R2) has the same size so that when calculated by the percentage inhibition formula it results in the number 0 which means no. there is a zone of inhibition.

\section{References}

[1] Agrios, G.N. 1997. Plant Pathology. 4th edition. Academic Press. New York.

[2] Radji. M. 2005. Peranan Bioteknologi Dan Mikroba Endofit Dalam Pengembangan Obat Herbal. Majalah Ilmu Kefarmasian 1: 113-126.

[3] Larran.S., A.Perello \& M.R.Simo'n. 2007. The endophytic fungi from wheat (Triticum aestivum L.). Microbiol Biotechnol 23: 565-572

[4] Bacon CW, Hinton DM. 2006. Bacterial endophytes: the endophytic niche, its occupants, and its utility. Di dalam: Gnanamanickam SS, editor. Plant-Associated Bacteria. Netherland: Springer.

[5] Barac T, Taghavi S, Borremas B, Provoost A, Oeyen L, Colpaert J V, Vangronsveld J, Lelie D V. 2004. Engineered endophytic bacteria improve phytoremediation of water-soluble, volatile, organic pollutants. Nature Biotech Vol 22.

[6] Simarmata, R. 2007. Isolasi Mikroba Endofitik dari Tanaman Obat Sambung Nyawa (Gynura Procumbens) dan Analisis Potensinya sebagai Antimikroba. Berk. Penel. Hayati (13) Hal: 1-6.

[7] Chandrashekhara. 2007. Endophytic Bacteria from Different Plant Origin Enhance Growth and Induce Downy Mildew Resistance in Pearl Millet. http://www.scialert.net/qredi 
rect.php?doi=ajppaj.2007.1.11\&linkid=pdf - similar by-SN-Chandrashekhara-2007.

[8] Diniyah, S. 2010. Potensi Isolat Bakteri Endofit sebagai Penghambat Pertumbuhan Bakteri(Ralstonia solanacearum) dan Jamur (Fusarium sp., dan Phytophora infestans) Penyebab Penyakit Layu pada Tanaman. Skripsi. Jurusan Biologi Fakultas Sains dan Teknologi. Malang: UIN (Tidak dipublikasi).

[9] Hallmann, J., 2001. Plant Interaction With Endophytic Bakteria. In: Jeger, M.J., And Spence, N.J., editor. Biotic Interaction in Plant-Pathogen Associations. CAB Internasional. P. 87-119.

[10] Lyon, G. 2007. Agents that Can Elicit Induced Resistance. In: Walters, D., Newton, A., Lyon, G. Editor. Induced Resistance for Plant Defence: Sustainable Approach to Crop Protection. Blackwell Publishing. pp.9-30.

[11] Verma, S. C., Singh, A., Chowdhury, S. P., and Tripathi, A. K. 2004. Endophytic colonization ability of two deep-water rice endophytes, Pantoea sp. and Ochrobactrum sp. using green fluorescent protein reporter. Biotechnol. Lett. 26: 425-429.

[12] Wakelin I, Mims, C., Dockrell, H. M., Roitt, Derek, Zuckerman, et al. 2004. Medical Microbiology.5th ed. Philadelphia: Elsevier.

[13] Lee J.Y., Hwang W. I., Lim S.T. 2004. Antioxidant and anticancer of organic extracts from Platycodon grandiflorum A. De Candolle roots. Journal of Ethnopharmacology 93: 409-15.

[14] Costa, J.M., Loper, J.E. 1994. Characterization of siderophore production by the biological-control agent Enterobacter cloacae. Mol. Plant-Microbe Interactions J., 7: 440-448

[15] Compant S, Duffy B, Nowak J, Clement C, Barka EA. 2005. Use of plant growth-promoting bacteria for biocontrol of plant diseases: Principles, Mechanisms of Action and future prospects. Applied and Environmental microbiology. Vol 71(9)

[16] Liu, L., Klopper, J.W dan Tuzun. 1995. Induction of Systemic Resistance in Cucumber Again Bacterial Angular Leaf Spot by Plant Growth Promoting Rhizobacteria. Phytopathology. 85. 843-846

[17] Kloepper, J.W. 1999. Plant Root-Bacterial Interaction in Biological Control of Soilborne Diseases and Potential Extention to Systemic and foliar Diseases. Australian Plant Pathology. 28: 21-26.

[18] Duangpaeng A, Phetcharat P, Chanthapho S, Boonkantong N, Okuda N. 2012. The study and development of endophytic bacteria for enhancing organic rice growth. Procedia Engineering. 32:172176. DOI: http://dx.doi.org/10.1016/j. proeng.2012.01.1253.

[19] Lopez BR, Tinoco-Ojanguren C, Bacilio M, Mendoza A, Bashan Y. 2012. Endophytic bacteria of the rock-dwelling cactus Mammillaria fraileana affect plant growth and mobilization of elements from rocks. Environmental and Experimental Botany. 81(2012):26-36. DOI: http://dx.doi. org/10.1016/j.envexpbot.2012.02.014.

[20] Nongkhlaw FM, Joshi SR. 2014. Epiphytic and endophytic bacteria that promote growth of ethnomedicinal plants in the subtropical forests of Meghalaya, India. Rev Biol Trop 62(4):1295-308. DOI: http://dx.doi. org/10.15517/rbt.v62i4.12138.

[21] Reitz M, Rudolph K, Schroeder I, Hoffmann- Hergarten S, Hallmann J, Sikora RA. 2000. Lipopolysccharides of Rhizobium etli G12 act in potato root as an inducing agent of systemic resistance to infection by the cyst nematode Globodera pallida. Applied and Environ. Microbiol 66(8):3515- 3518. DOI: http://dx.doi.org/10.1128/ AEM.66.8.3515-3518.2000.

[22] Strobel, G. A. \& B. Daisy, 2003. Bioprospecting for Microbial Endophytes and Their Natural Products. Microbiology and Molecular Biology. 419-502.

[23] Schulz.B J.E., C.J.C. Boyle \& T. N. Sieber (Eds.). 2006. What are Endophytes?. Microbial Roots Endophytes. Springer-Verlag Berlin Heidelberg. Germany.

[24] Rahma, H. 2000. Studi Peningkatan Ketahanan Tanaman Kedelai Terhadap Penyakit Pustul Bakteri Menggunakan Pseudomonas yang Berfluoresensi [Thesis]. Program Pascasarjana Universitas Andalas Padang.

[25] Hung P Q dan Annapurna K. 2004. Isolation and characterization of endophytic bacteria in soybean (Glycine sp.) Omontie 12: 92-101 